\title{
MODEL DUGAAN VOLUME DAN RIAP TEGAKAN JATI (Tectona grandis L.F) DI NUSA PENIDA, KLUNGKUNG BALI
}

\author{
(Volume Estimation Model and Increment of Teakwood Stand \\ at Nusa Penida, Klungkung Bali) \\ I Wayan Widhana Susila \\ Balai Penelitian Kehutanan Mataram \\ Jl. Dharma Bhakti No. 7-Po Box 1054, Ds. Langko, Kec. Lingsar Lombok Barat NTB 83371, \\ Telp. (0370) 6573874, Fax. (0370) 6573841, \\ Email : bpkmataram@yahoo.co.id
}

Naskah masuk : 26 Oktober 2011; Naskah diterima : 31 Juli 2012

\begin{abstract}
Community teakwood plantation (Tectona grandis L.f) has been grown at Nusa Penida on unused and critical land. However, quantitative information about growth and potency of teakwood stand is still rare. The research was aimed to obtain volume estimation model and increment information of teakwood stand. The research was conducted at six villages from May to June 2009. The parameter measured in a survey of potency were diameter (D), height of tree (T), age of stand, density of stand, etc. Based on survey result, 117 trees were sellected for tree volume estimation by measuring the actual volume through measuring diameter of stem in each section (1 $\mathrm{m}$ length). The results were follow : 1) the estimation model of volume until stem height with $10 \mathrm{~cm}$ diameter were $\tilde{v}=0.00006 D^{2,660}$ and $\tilde{v}=$ $0.00012 D^{1,967} T^{0,673}$, until height of branch free stem were $\widetilde{v}=0.000245 D^{2,109}$ and $\tilde{v}=0.00011 D^{2,017} T^{0,631}$, and until height of crown base were $\tilde{v}=0.00025 D^{2,084}$ and $\left.\tilde{v}=0.00011 D^{2,014} T^{0,663} ; 2\right)$ the form factor of stem until height of stem with $10 \mathrm{~cm}$ diameter was 0.72 ; and 3) the increment of teakwood stand were diameter increment up to $2.25 \mathrm{~cm} / y e a r$ and heiht increment up to $1.97 \mathrm{~m} /$ year.
\end{abstract}

Keywords: Nusa Penida, estimation model of volume, teakwood (T. grandis L.f)

\begin{abstract}
ABSTRAK
Hutan rakyat jati (Tectona grandis L.f) sudah banyak dikembangkan di Kecamatan Nusa Penida, umumnya ditanam pada lahan-lahan kosong dengan kondisi tanah relatif kritis. Akan tetapi, Informasi kuantitatif seperti data riap dan potensi tegakan jati masih relatif kurang. Penelitian bertujuan memperoleh model dugaan volume dan informasi riap tegakan jati. Penelitian dilakukan secara purposive sampling di enam desa pada bulan Mei hingga Juni 2009, dengan melakukan survey potensi jati yang berdiameter batang $(\mathrm{dbh}) \geq 10 \mathrm{~cm}$. Parameter yang diukur pada setiap pohon adalah diameter dbh (D), tinggi pohon (T), tahun tanam, kerapatan tegakan, dan lain-lain. Berdasarkan hasil survey, dipilih 117 pohon sebagai pohon contoh dengan melakukan pengukuran batang perseksi setiap panjang $1 \mathrm{~m}$ untuk memperoleh volume pohon jati aktual. Hasil penelitian adalah sebagai berikut : 1) model penduga volume pada tinggi pohon diameter $10 \mathrm{~cm}$ adalah $\tilde{v}=0,00006 \mathrm{D}^{2,660}$ dan $\tilde{v}=0,00012 \mathrm{D}^{1,967} \mathrm{~T}^{0,673}$, pada tinggi pohon bebas cabang adalah $\tilde{v}=0,000245 \mathrm{D}^{2,109}$ dan $\tilde{v}=0,00011 \mathrm{D}^{2,017} \mathrm{~T}^{0,631}$, dan pada tinggi pohon pangkal tajuk adalah $\tilde{v}=0,00025 \mathrm{D}^{2,084}$ dan $\left.\tilde{v}=0,00011 \mathrm{D}^{2,014} \mathrm{~T}^{0,663} ; 2\right)$ angka bentuk batang jati rata-rata (f) adalah adalah 0,72 ; dan 3) riap tegakan jati adalah riap diameter sampai $2,25 \mathrm{~cm} /$ tahun dan riap tinggi pohon sampai $1,97 \mathrm{~m} / \mathrm{tahun}$.
\end{abstract}

Kata kunci : Nusa Penida, model penduga volume, jati (T. grandis L.f)

\section{PENDAHULUAN}

Pemasukan (kebutuhan) kayu di Provinsi Bali mencapai 59.342,77 $\mathrm{m}^{3}$ (Dinas Kehutanan Provinsi Bali, 2006). Sedangkan produksi kayu dari kawasan hutan (kawasan hutan produksi) kemungkinan tidak ada, karena hampir 98\% dari luas kawasan hutan merupakan kawasan fungsi lindung dan kawasan konservasi. Kemungkinan relatif kecil yang dapat dipenuhi dari potensi hutan rakyat (kebun rakyat), namun informasi potensinya belum terdokumentasi dengan akurat.

Adanya ketimpangan yang relatif besar antara supply dan demand kayu di Bali menyebabkan setiap tahun nilai pasar kayu olahan terus merambat naik sehingga komoditas 
kayu mempunyai prospek yang sangat bagus untuk dikembangkan. Menyadari hal tersebut, masyarakat petani di Nusa Penida sedang mengembangkan berbagai jenis komoditi kehutanan dengan jenis yang cocok dan bernilai ekonomis pada lahan miliknya seperti jenis jati (Tectona grandis L.f.), mahoni (Swietenia macrophylla King.), gmelina (Gmelina arborea Roxb.) dan jenis pohon lainnya.

Tanaman jati di hutan rakyat sudah banyak dikembangkan di Kecamatan Nusa Penida Kabupaten Klungkung, terutama menyebar di Desa Suwana, Pejukutan, Bunga Mekar, Desa Ped, Klumpu, dan Desa Kutampi. Berdasarkan survey pendahuluan, sebaran umur dan potensi tegakan jati pada lokasi tersebut relatif beragam, yaitu dari umur 6 tahun 26 tahun dan lebih dari diameter $1035 \mathrm{~cm}$ tahun. Umur daur tebang yang diterapkan oleh masyarakat petani pada umumnya tidak menentu, tegantung kebutuhan petani, nilai jual dan pembeli kayu. Hasil wawancara dengan tokoh masyarakat, aparat kecamatan dan staf kehutanan Dinas DKLH Kabupaten Klungkung, pada umumnya masyarakat Nusa Penida menanam jati pada lahan-lahan yang kosong dengan kondisi tanah yang relatif kritis. Jenis jati sangat diminati masyarakat karena mempunyai keunggulan yang tidak dimiliki oleh jenis lain, yaitu termasuk kayu kelas I, kuat, awet, mudah dikerjakan, memiliki penampilan yang menarik dan nilai jualnya tinggi (Anonim, 1994).

Tegakan hutan rakyat jati yang telah berhasil dibangun di Nusa Penida tersebut perlu dikelola dengan manajemen yang baik agar pertumbuhan tegakannya optimal. Data mengenai hutan rakyat jati yang belum tersedia adalah data seperti riap dan potensi/volume tegakan. Pengetahuan volume pohon sangat diperlukan masyarakat petani untuk menghindari kerugian yang sering diperlakukan oleh para pembeli/ tengkulak kayu jati di lapangan. Riap volume tanaman jati dapat mencapai $7,9-10 \mathrm{~m}^{3} / \mathrm{ha} /$ tahun (http://sahabatlingkungan.multiply. com/journal/ item/19, 2008). Informasi di KPH Nganjuk menyebutkan bahwa riap diameter jati dari trubusan akar mencapai 25 - $28 \mathrm{~cm}$ pada umur 20 tahun, sedangkan riap diameter tanaman aslinya hanya 1 - $2 \mathrm{~cm} /$ tahun (http://www.suarakarya-online. com/news.htmlid=123303, 2005). Susila (2009) menyebutkan riap jati pada umur 10 tahun di Takari Kabupaten Kupang adalah diameter 1,4 cm/ tahun dan tinggi pohon $1,5 \mathrm{~m} /$ tahun, sedangkan di Polen Timor Tengah Selatan pada umur 8 tahun lebih rendah yaitu $1,0 \mathrm{~cm} /$ tahun dan $0,8 \mathrm{~m} /$ tahun.
Data potensi tegakan pada umumnya diperoleh dari hasil kegiatan inventarisasi, dimana dalam inventarisasi tersebut massa tegakan ditaksir melalui pendugaan volume setiap pohon penyusun tegakan yang bersangkutan. Beragamnya keadaan tegakan menurut tempat tumbuh dan lingkungannya menyebabkan bentuk batang pohon bervariasi dari suatu kondisi tempat tumbuh dengan kondisi tempat tumbuh yang berbeda. Sehubungan dengan itu, cara penaksiran volume pohon secara seragam dengan menggunakan perangkat penduga volume pohon yang menggunakan satu macam angka bentuk batang sebaiknya dihindarkan karena hal tersebut merupakan sumber kesalahan hasil taksiran. Sampai saat ini perangkat penduga volume pohon jati di Nusa Penida belum tersedia. Untuk itu, penelitian ini bertujuan untuk memperoleh model pendugaan volume dan riap tegakan jati di Nusa Penida.

\section{BAHAN DAN METODE}

\section{A. Lokasi Penelitian}

Lokasi penelitian di Desa Suana (letak geografis $03^{\circ} 45^{\circ} 659^{\prime \prime} \mathrm{LS}, 90^{\circ} 35^{`} 038^{\prime \prime}$ BT dan ketinggian $50 \mathrm{~m} \mathrm{dpl}$ ), Desa Pejukutan (letak geografis $03^{\circ} 44^{\prime} 661^{\prime}$ ' LS, $90^{\circ} 32^{`} 644^{\prime \prime}$ BT dan ketinggian $220 \mathrm{~m} \mathrm{dpl}$ ), Bunga Mekar (letak geografis $03^{\circ} 34^{\prime} 477^{\prime \prime} \mathrm{LS}, 90^{\circ} 34^{\prime} 202^{\prime \prime}$ BT dan ketinggian 150 - $200 \mathrm{~m} \mathrm{dpl),} \mathrm{Desa} \mathrm{Ped} \mathrm{(letak}$ geografis $03^{\circ} 37^{`} 248^{\prime \prime} \mathrm{LS}, 90^{\circ} 39^{`} 703^{\prime \prime} \mathrm{BT}$ dan ketinggian $50 \mathrm{~m} \mathrm{dpl}$ ), Klumpu (letak geografis $03^{\circ} 39^{\prime} 827^{\prime \prime}$ LS, 90 36 $288^{\circ}$ ” BT dan ketinggian $150 \mathrm{~m} \mathrm{dpl}$ ), dan Desa Kutampi (letak geografis $03^{\circ} 40^{\prime} 785^{\prime}$ " LS, 90 $38^{\circ} 124$ ” BT dan ketinggian $200 \mathrm{~m} \mathrm{dpl}$ ). Posisi letak lokasi-lokasi penelitian tanaman jati di Pulau Nusa Penida dapat dilihat pada Gambar 1. Kegiatan penelitian dilaksanakan dari bulan Mei hingga Juni 2009. Jarak tanam rata-rata 3 hingga $6 \mathrm{~m}$, beberapa lokasi tumpang sari dengan tanaman ketela pohon. Asal-usul bibit sebagian lokasi bantuan dari Dinas Kehutanan Provinsi Bali dan sebagian lagi dengan swadana yang berasal dari Kecamatan Melaya Kabupaten Jembrana, Bali Barat. Jumlah pohon dan kondisi tegakan jati yang diamati pada setiap desa adalah sebagai berikut :

a) Desa Suana : jumlah jati 30 pohon, tahun tanam 1991, jarak tanam 3-5 m.

b) Desa Pejukutan : jumlah 60 pohon, tahun tanam 1996 - 1997, jarak tanam 3 - 5 m, 
bercampur dengan tanaman Gmelina (Gmelina arborea).

c) Desa Bunga Mekar: jumlah 68 pohon, tahun tanam 2000, jarak tanam 3 - 6 m, ada tanaman singkong.

d) Dusun Seming, Desa Ped: jumlah 25 pohon, tahun tanam 1998 - 2002, jarak tanam 2 - 5 m, bercampur dengan tanaman gamal.

e) Desa Klumpu : jumlah jati 25 pohon, tahun tanam 1997-2003, jarak tanam 3-7 m.

f) Desa Kutampi : jumlah jati di ukur 25 pohon, tahun tanam 1983 -1985, jarak tanam 2 - $5 \mathrm{~m}$.

Nusa Penida pada umumnya beriklim tropis dengan suhu rata-rata antara $25^{\circ} \mathrm{C}$ hingga $33^{\circ} \mathrm{C}$, dengan curah hujan tahunannya relatif sangat rendah. Hasil pengamatan 10 tahun (1990 - 2000) menunjukkan bahwa curah hujan ratarata adalah 975,6 mm/tahun, jumlah hari hujan rata-rata adalah 66,8 hari/tahun dengan intensitas hujan bulanan rata-rata sebesar $14,6 \mathrm{~mm} / \mathrm{jam}$, sehingga Kepulauan Nusa Penida termasuk tipe iklim E (DKLH Klungkung, 2002). Lebih lanjut dinyatakan bahwa sebagian besar lahan di Nusa Penida bertopografi berbukit dengan kelerengan agak curam (di atas $15 \%$ ), yaitu tercatat lahan seluas 18.282 ha (sekitar $90 \%$ dari total wilayah) diklasifikasikan sebagai lahan dengan kelerengan agak curam hingga sangat curam.
Kesuburan tanah rendah dengan solum sebagian besar di bawah $15 \mathrm{~cm}$. Berdasarkan analisis sampel tanah oleh Universitas Udayana Denpasar tahun 1998, diketahui bahwa 88,4\% lahan bertekstur tanah lempung sedang sampai halus, struktur granuler gumpal/lempung pejal, permeabilitas tanah sedang, agregat (butiran tanah) sedang, porositas tanah agak poros (lambat sampai sedang) (Badang Litbang Kehutanan, 2004).

\section{B. Bahan dan Alat}

Bahan penunjang dan peralatan untuk kegiatan penelitian adalah tegakan hutan rakyat, cat (untuk penandaan), kompas (penunjuk arah), hagameter (pengukur tinggi pohon), galah (alat pengukur tinggi pohon), pitameter (pengukur keliling pohon), tangga (alat panjat), parang dan sabit (perintisan dan pembersihan/pembabatan lokasi), Kamera (untuk dokumentasi), tallysheet (blangko pencatatan), obat-obatan (P3K) dan alat tulis-menulis.

\section{Pengumpulan Data}

Penelitian diawali dengan pencatatan data sebaran tanaman jati setiap desa melalui wawancara di kantor kecamatan Nusa penida.

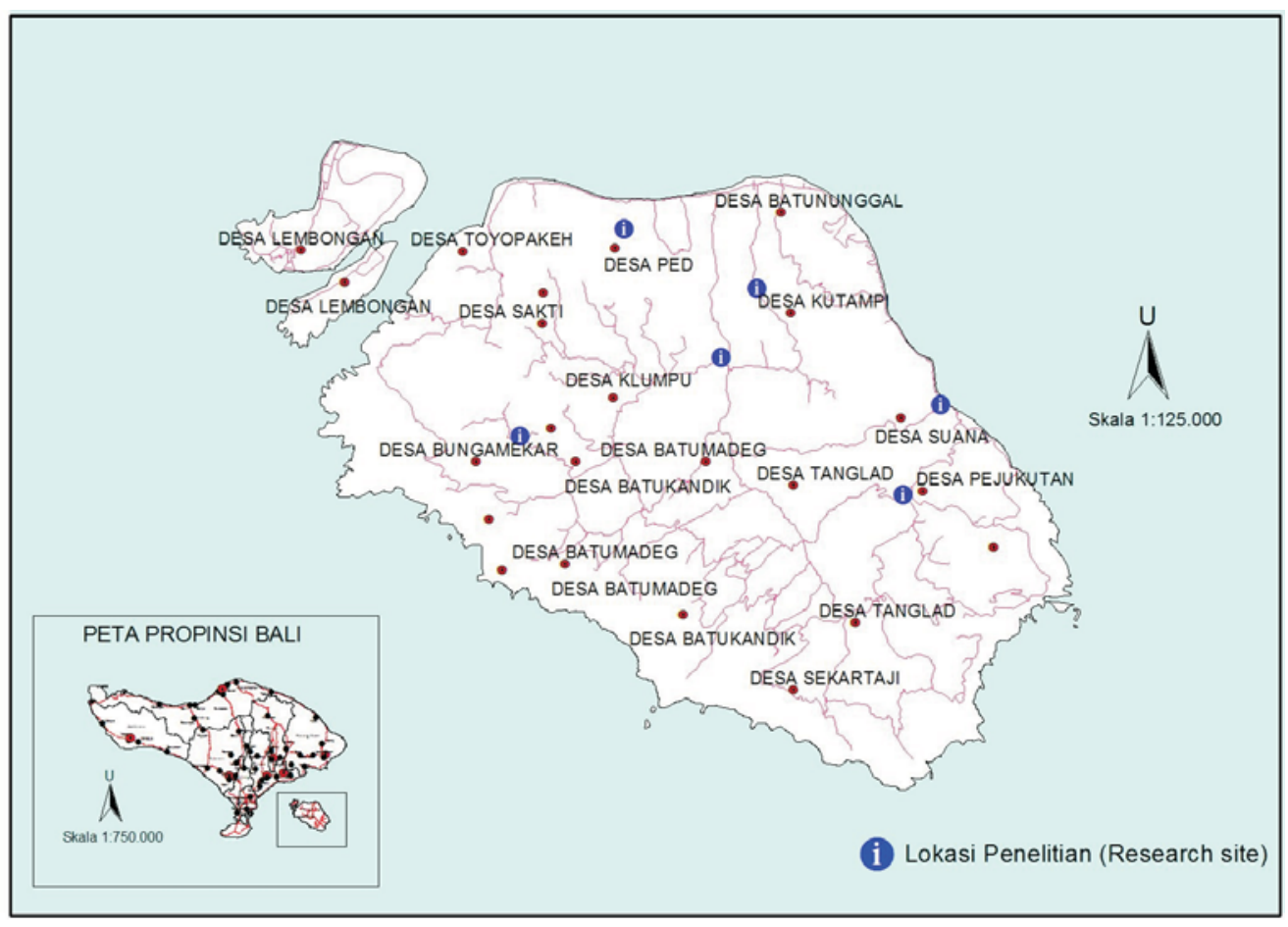

Gambar(Figure) 1. Sebaran lokasi pengamatan jati di Nusa Penida (Distribution of teakwood observation site at Nusa Penida) 
Kemudian secara purposive sampling dipilih 6 desa tersebut di atas, dengan alasan umur tegakan jati yang relatif tua dan keragaman diameter dbh di atas $10 \mathrm{~cm}$. Di setiap desa terpilih tersebut dilakukan pencatatan data kepemilikan lahan hutan rakyat jati melalui wawancara di kantor desa dengan staf desa dan tokoh masyarakat di desa tersebut, yang diarahkan pada tanaman jati berdiameter rata-rata lebih dari $10 \mathrm{~cm}$. Berdasarkan data kepemilikan tegakan hutan rakyat jati maka dipilih 6 orang petani pemilik lahan yang masing-masing mewakili pemilikan tegakan jati pada setiap desa. Parameter yang diukur pada setiap pohon adalah diameter setinggi dada dan tinggi pohon total, umur tegakan (tahun tanam), kerapatan (jarak tanam), dan jenis tanaman tumpang sari.

Semua data hasil pengukuran yang terkumpul dari semua desa dihimpun menjadi satu dan dibuat grafik sebaran pohon menurut diameter dan tinggi seperti ilustrasi pada Gambar 2 (Harbagung, 2002).

Berdasarkan hasil Gambar 2 maka dipilih pohon contoh sebanyak 117 pohon dengan diameter batang $\mathrm{dbh} \geq 10 \mathrm{~cm}$ atau keliling batang $\geq 31 \mathrm{~cm}$, yang menyebar pada setiap desa adalah desa Suana 17 pohon, Desa Pejukutan 37 pohon, Desa Ped 10 pohon, Desa Bunga Mekar 31 pohon, Desa Klumpu 10 pohon, dan Desa Kutampi 12 pohon.
Parameter yang diukur terhadap pohon contoh adalah diameter batang setinggi dada (dbh), tinggi pohon bebas cabang, tinggi pohon sampai keliling batang dan cabang $31 \mathrm{~cm}$, tinggi pohon sampai pangkal tajuk dan keliling batang perseksi setiap panjang $1 \mathrm{~m}$. Pengukuran dilakukan dengan pemanjatan batang dan cabang pohon, seksi pertama diukur pada diameter pohon setinggi $30 \mathrm{~cm}$ dari permukaan tanah kemudian batang pohon pokok bebas cabang dibagi menjadi seksi-seksi sepanjang $1 \mathrm{~m}$. Pengukuran keliling cabang dilakukan apabila ukurannya $\geq 31 \mathrm{~cm}$.

\section{Analisis Data}

Volume pohon merupakan jumlah volume setiap seksi dari pohon yang bersangkutan, Volume setiap seksi dihitung dengan rumus Smallian (Prodan, 1965):

$$
\mathrm{V}_{\mathrm{S}}=\frac{\mathrm{B}=\mathrm{b}}{2} \times \mathrm{L}
$$

Keterangan (Remarks) : $V_{s}$ adalah volume seksi batang, $B$ adalah luas bidang dasar pangkal seksi, $b$ adalah luas bidang dasar ujung seksi, dan $L$ adalah panjang seksi.

Angka bentuk batang (f) dihitung sebagai perbandingan antara isi kayu melalui perhitungan

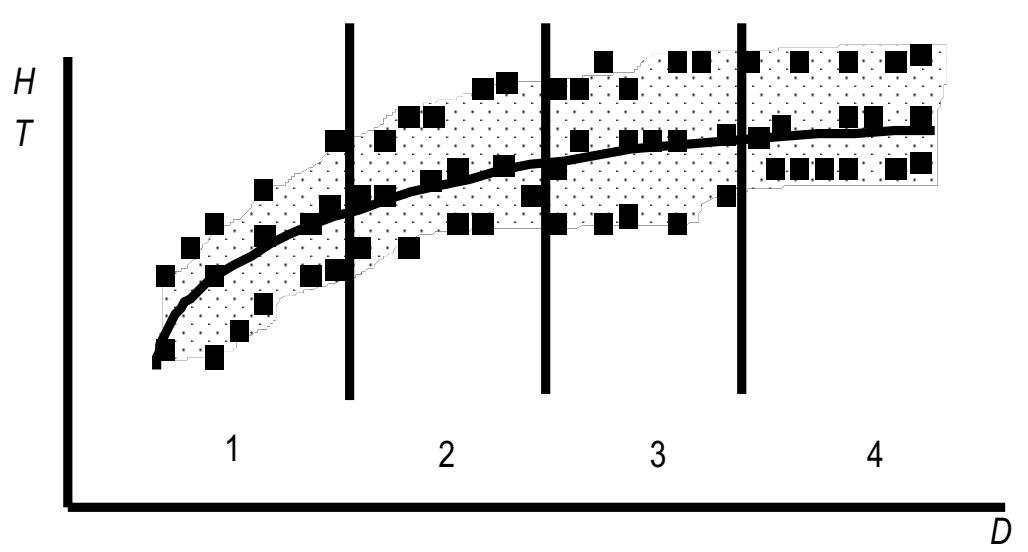

Keterangan (Remarks) :

$=$ Titik-titik kecil adalah menggambarkan sebaran pohon menurut $\mathrm{D}$ dan $\mathrm{H}$ (Small spots are distribution of tree based diameter and height of tree)

= Garis lengkung adalah kurva yang ditarik dengan cara tangan bebas menggambarkan nilai rata-rata T pada setiap kelas dbh, (Curve is made through freehand method to describe mean value of height for diameter class)

$=$ Titik-titik besar merupakan pohon-pohon yang terpilih, yaitu masing-masing tersebar di bawah, dekat dan di atas garis grafik (Large spots is tree of selected, each distributed under, on and to curve)

Gambar(Figure)2. Contoh sebaran pohon menurut Dbh dan T (Sample of trees distribution based on diametre and height) 
volume per seksi dengan isi silinder yang mempunyai dbh dan tinggi pohon yang sama. Pengujian hipotesa angka bentuk batang dengan 0,70 dilakukan dengan uji $\mathrm{t}$ sebagai berikut (Irianto, 2006) :

Ho : $\mathrm{F}=0,70$ lawan $\mathrm{H} 1: \mathrm{F} \neq 0,70$

$\mathrm{Thit}=(\mathrm{f}-\mathrm{F}) / \mathrm{Sf}$ derajat bebas (n-1)

Keterangan (Remarks) : F adalah angka bentuk batang hipotetik, $f$ adalah rata-rata dari angka bentuk pohon, dan $\mathrm{Sf}=$ kesalahan baku angka bentuk batang.

Model pendugaan volume pohon disusun dengan analisis regresi. Bentuk umum dari persamaan regresi yang dianalisis adalah sebagai berikut:

$$
\widetilde{\mathrm{V}}=f(\mathrm{D}, \mathrm{T})
$$

Keterangan (Remarks) : V adalah volume batang pohon sampai tinggi pohon tertentu, D adalah diameter setinggi dada, Tadalah tinggi pohon tertentu.

Program yang dipergunakan untuk proses pengolahan data model pendugaan volume pohon adalah program Microsoft Office Excell dan Program statistik SPSS 11.5. Dari programprogram statistik tersebut, banyak diperoleh model-model persamaan regresi. Akan tetapi, model yang lebih sederhana seperti regresi linear untuk menduga volume pohon berdiri dapat dinotasikan sebagai berikut (Simon, 2007):

a) Satu peubah (diameter)

$$
\widetilde{\mathrm{v}}=\mathrm{a}+\mathrm{bD}
$$$$
\log \widetilde{v}=\log a+b \log D \text { atau } V=a D^{b}
$$

b) Dua peubah (diameter dan tinggi pohon)

$$
\widetilde{\mathrm{v}}=\mathrm{a}+\mathrm{bD}+\mathrm{cT}
$$

$\log \widetilde{v}=\log a+b \log D+c \log T$ atau $V=a$ $\mathrm{D}^{\mathrm{b}} . \mathrm{T}^{\mathrm{c}}$

Keterangan (Remarks) : $\widetilde{\mathrm{v}}$ adalah volume dugaan pohon tertentu, D adalah diameter setinggi $1,30 \mathrm{~cm}$, dan $\mathrm{a}, \mathrm{b}$ dan $\mathrm{c}$ adalah konstanta.

Ukuran keseksamaan model volume didasarkan pada pertimbangan kecilnya persen kesalahan baku (Se), simpangan agregatif (SA) dan Simpangan Rata-Rata (SR). SA dan SR dihitung berdasarkan rumus Bruce yang ditulis oleh Husch (1963), sebagai berikut:

$$
\begin{aligned}
& \mathrm{SA}=(\Sigma \mathrm{V}-\Sigma \widetilde{\mathrm{V}}) / \Sigma \mathrm{V} \times 100 \% \\
& \mathrm{SR}=\Sigma(\mid \mathrm{V}-\widetilde{\mathrm{V}} / \mathrm{V}) / \mathrm{N} \times 100 \%
\end{aligned}
$$

Keterangan (Remarks) : V adalah volume aktual, $\widetilde{\mathrm{V}}$ adalah volume dugaan, dan $\mathrm{N}$ adalah jumlah pohon contoh.
Informasi riap tegakan (mean annual increment - MAI) dapat disajikan dengan perhitungan sebagai berikut :

$$
\mathrm{I}=\Sigma(\mathrm{Y} / \mathrm{A}) / \mathrm{N}
$$

Keterangan (Remarks) : I adalah rata-rata riap tahunan jati, Y adalah diameter, tinggi, atau volume pohon, A adalah umur pohon, dan $\mathrm{N}$ adalah jumlah pohon jati.

\section{HASIL DAN PEMBAHASAN}

\section{A. Angka Bentuk Pohon}

Angka bentuk batang jati (f) dihitung sebagai perbandingan antara isi kayu melalui perhitungan volume per seksi dengan isi silinder yang mempunyai diameter batang setinggi dada $(1,30 \mathrm{~m})$ dan tinggi pohon pada diameter batang/ cabang minimal $10 \mathrm{~cm}$. Nilai angka bentuk setiap individu pohon disajikan pada Tabel 1. Nilai ratarata angka bentuk batang pohon jati adalah $\mathrm{f}=$ 0,72 . Sebagian besar pohon model mempunyai angka bentuk antara $0,66-0,75$ dan $0,56-0,65$, masing-masing sebanyak 46 pohon $(39,32 \%)$ dan 35 pohon $(29,91 \%)$ (Tabel 2).

Berdasarkan sebaran nilai angka bentuk seperti Tabel 1, maka dapat ditentukan simpangan bakunya yaitu 0,124631 . Kesalahan baku angka bentuk batang adalah simpangan baku dibagi dengan akar dari jumlah pohon contoh yaitu $0,124631 /(117)^{1 / 2}=0,011522$. Berdasarkan uji t; $t-$ hitungnya adalah 1,736 , sedangkan t-tabel dengan derajat bebas 120 dengan taraf nyata $95 \%$ $\left(\mathrm{t}_{0,025 ; 120}\right)$ adalah 1,983 (Irianto,2004). Berarti thitung lebih kecil dari pada t-tabel, oleh karena itu hipotesis angka bentuk $(F)=0,70$ yang dipergunakan dalam pendugaan volume batang jati diterima. Hal ini berarti dengan menggunakan angka bentuk $(\mathrm{F})=0,70$ terhadap prediksi volume jati berdiri sampai tinggi pohon pada diameter batang/ cabang $\geq 10 \mathrm{~cm}$ menghasilkan dugaan yang underestimate (kurang dari volume kayu sebenarnya) sebesar 2,8 \%. Hasil bias (penyimpangan) volume ini relatif kecil yaitu kurang dari $10 \%$. Pada Tabel 1 dapat dilihat mengenai variasi angka bentuk pohon, yaitu sebagian besar nilai angka bentuk pohon cenderung mendekati nilai antara $0,60-0,75$, dan didukung juga oleh Tabel 2 bahwa 39,3\% dari populasi pohon yang diamati mempunyai angka bentuk di sekitar 0,70 (selang $0,66-0,75$ ). 
Tabel (Table) 2. Sebaran frekuensi angka bentuk batang (Frequency distribution of stem form factor)

\begin{tabular}{|c|c|c|c|}
\hline $\begin{array}{c}\text { Angka Bentuk } \\
\text { (Form Factor })\end{array}$ & $\begin{array}{c}\text { Nilai Tengah } \\
(\text { Mean })\end{array}$ & $\begin{array}{c}\text { Frekuensi } \\
(\text { Frequency })\end{array}$ & $\begin{array}{c}\text { Persentase } \\
(\text { Percentage }) \%\end{array}$ \\
\hline $0,46-0,55$ & 0,50 & 5 & 4,27 \\
$0,56-0,65$ & 0,60 & 35 & 29,91 \\
$0,66-0,75$ & 0,70 & 46 & 39,32 \\
$0,76-0,85$ & 0,80 & 15 & 12,82 \\
$0,86-0,95$ & 0,90 & 7 & 5,98 \\
$>0,95$ & - & 9 & 7,69 \\
\hline Jumlah & 0,72 & 117 & 100,00 \\
\hline
\end{tabular}

\section{B. Model Penduga Volume Pohon}

\section{Model volume pada tinggi batang diameter $10 \mathrm{~cm}$}

Model-model penduga volume jati pada tinggi pohon diameter $10 \mathrm{~cm}$ sesuai galat baku (Se) dan koefesien determinasinya $\left(\mathrm{R}^{2}\right)$ disajikan pada Tabel 3. Model-model terpilih pada tabel tersebut memenuhi persyaratan untuk menduga volume pohon sesuai yang diperkenankan. Menurut Marcelino (1960) dan Prodan (1965) dalam Bustomi dan Soemarna (1986), dalam menyusun model berdasarkan persamaan regresi yang menggunakan satu peubah diperkenankan kesalahan baku (Se) maksimal $25 \%$, sedangkan apabila menggunakan dua peubah diperkenankan kesalahan baku maksimal $20 \%$. Berdasarkan nilai Se dengan satu variabel, model kuadrati termasuk model linear berganda (model nomor 1) yang paling akurat digunakan untuk menaksir volume pohon jati, karena mempunyai nilai Se yang paling rendah. Hal ini berarti tingkat akurasi (ketepatan) model kuadrati tersebut untuk menduga volume pohon sengon adalah paling tinggi (tepat). Akan tetapi, penggunaan model tersebut relatif kurang aplikabel di lapangan karena tingkat kesulitan perhitungannya relatif lebih tinggi dari kedua model linear dan power (model nomor 3 dan 4), meskipun mempunyai Se yang relatif lebih tinggi atau tingkat akurasi yang lebih rendah. Pada Tabel 3 dapat juga dilihat bahwa, penambahan variabel tinggi menjadi seperti model nomor 2 yang termasuk juga model linear berganda yang mempunyai $\mathrm{Se}=3,73 \%$; tingkat akurasi dugaan meningkat sampai 0,8\% jika dibandingkan dengan model linear nomor 3 yang mempunyai nilai $\mathrm{Se}=3,76 \%$. Demikian pula untuk model power, dengan penambahan variabel tinggi menjadi model nomor 4 mempunyai nilai $\mathrm{Se}=4,31 \%$; tingkat akurasi dugaan meningkat sampai $40 \%$ jika dibandingkan dengan model power nomor 5 (tanpa variabel T).

Koefesien determinasi $\left(\mathrm{R}^{2}\right)=92,80 \%$ pada model nomor 2 berarti hampir $93 \%$ variasi volume pohon jati pada tinggi pohon diameter $10 \mathrm{~cm}$ disebabkan oleh variasi diameter dan tinggi dalam persamaan tersebut (dua variabel). Sedangkan, $\mathrm{R}^{2}=92,61 \%$ pada model nomor 3 artinya lebih dari $92 \%$ variasi volume disebabkan oleh variasi diameter saja dalam persamaan tersebut (satu variabel). Pengaruh parameter tinggi pohon yang relatif rendah dapat dijelaskan juga dari nilai koefesien determinasi antara diameter dan tinggi pohon yaitu 65,9\%, artinya besarnya diameter dan tinggi pohon berbanding lurus dengan peluang lebih dari $50 \%$. Untuk model power (pangkat), dengan penambahan variabel $\mathrm{T}$ seperti model nomor 4 (dua variabel) mempunyai $\mathrm{Se}=4,31 \%$ lebih rendah dari pada $\mathrm{Se}=7,20 \%$ model nomor 5 (satu variabel diameter). Dengan demikian, penambahan explanatory variable T pada model pangkat tersebut meningkatkan akurasi dugaan meningkat relatif tinggi sebesar $40 \%$.

Ukuran kesaksamaan model volume didasarkan pada pertimbangan kecilnya persen kesalahan baku $(S e)$, simpangan agregatif $(S A)$ dan simpangan rataan $(S R)$. Lima model tersebut di atas, dan model dengan menggunakan angka bentuk batang $(\mathrm{f})=0,72$ yaitu $\widetilde{v}=1 / 4 \Pi(0,01 \mathrm{D})^{2}$. $\mathrm{T}$. $\mathrm{f}=0,25 \times 3,142 \times(0,01)^{2} \times 0,72 \times \mathrm{D}^{2} \mathrm{~T}=$ $0,000057 \mathrm{D}^{2} \mathrm{~T}$ disajikan pada Tabel 4. Model persamaan $\widetilde{v}=0,000057 \mathrm{D}^{2} \mathrm{~T}$ mempunyai nilai Se yang relatif rendah, yaitu 1,47\%. 
Tabel(Table) 3. Model-model dugaan volume pada tinggi pohon diameter batang $10 \mathrm{~cm}$ (Volume estimation models on tree height of $10 \mathrm{~cm}$ stem diameter)

\begin{tabular}{|c|l|l|c|c|}
\hline No. & \multicolumn{1}{|c|}{$\begin{array}{c}\text { Model Regresi } \\
\text { (Regression Models) }\end{array}$} & \multicolumn{1}{|c|}{$\begin{array}{c}\text { Persamaan Regresi } \\
\text { (Regression Equations) }\end{array}$} & Se (\%) & $\mathrm{R}^{2}(\%)$ \\
\hline 1 & Kuadrati & $\widetilde{\mathrm{v}}=-0,075+0,004 \mathrm{D}+0,0005 \mathrm{D}^{2}$ & 3,44 & 93,86 \\
2 & Linear & $\widetilde{\mathrm{v}}=-0,253+0,021 \mathrm{D}+0,004 \mathrm{~T}$ & 3,73 & 92,80 \\
3 & Linear & $\widetilde{\mathrm{v}}=-0,248+0,023 \mathrm{D}$ & 3,76 & 92,61 \\
4 & Power & $\widetilde{\mathrm{v}}=0,00012 \mathrm{D}^{1,967} \mathrm{~T}^{0,673}$ & 4,31 & 98,60 \\
5 & Power & $\widetilde{\mathrm{v}}=0,00006 \mathrm{D}^{2,660}$ & 7,20 & 96,10 \\
\hline
\end{tabular}

Keterangan (remark):

$\widetilde{\mathrm{V}}=$ Dugaan volume pada tinggi pohon diameter $10 \mathrm{~cm}$ (Volume estimation on tree height of $10 \mathrm{~cm}$ diameter)

$\mathrm{D}=$ Diameter setinggi dada (Diameter at breast height)

$T=$ Tinggi pohon pada diameter $10 \mathrm{~cm}$ (Height of tree on $10 \mathrm{~cm}$ diameter)

Tabel (Table) 4. SA dan SR persamaan regresi volume pohon (Agregative deviation and mean deviation of volume regression equation on tree height of $10 \mathrm{~cm}$ stem diameter)

\begin{tabular}{|l|l|c|c|c|}
\hline No. & \multicolumn{1}{|c|}{$\begin{array}{c}\text { Persamaan Regresi } \\
\text { (Regression Equations) }\end{array}$} & SA (\%) & SR (\%) & $\begin{array}{c}\text { Keterangan } \\
(\text { Remarks })\end{array}$ \\
\hline 1 & $\widetilde{\mathrm{v}}=-0,248+0,023 \mathrm{D}$ & $-2,21$ & 24,38 & Satu variabel \\
2 & $\widetilde{\mathrm{v}}=-0,075+0,004 \mathrm{D}+0,0005 \mathrm{D}^{2}$ & $-6,95$ & 13,91 & \\
3 & $\widetilde{\mathrm{v}}=0,00006 \mathrm{D}^{2,660}$ & 1,45 & 13,13 & \\
\hline 4 & $\widetilde{\mathrm{v}}=-0,253+0,021 \mathrm{D}+0,004 \mathrm{~T}$ & 3,75 & 27,51 & Dua variabel \\
5 & $\tilde{\mathrm{v}}=0,00012 \mathrm{D}^{1,967} \mathrm{~T}^{0,673}$ & 0,13 & 7,99 & \\
6 & $\tilde{\mathrm{v}}=0,000057 \mathrm{D}^{2} \mathrm{~T}$ & $-9,15$ & 13,09 & \\
\hline
\end{tabular}

Pada Tabel 4 dapat dilihat bahwa model persamaan nomor 1,2 dan 6 cenderung menduga volume pohon kurang dari volume pohon aktual (underestimate) karena nilai SA adalah negatif. Persamaan nomor 1 kekurangannya paling rendah, yaitu hampir $2 \%$ dari nilai sebenarnya, namun simpangan rataannya lebih dari $20 \%$. Sebaliknya, model persamaan nomor 3, 4 dan 5 menduga volume pohon lebih dari volume sebenarnya (overestimate). Model nomor 3 (satu variabel) mempunyai SA lebih kecil dari pada model nomor 4 (dua vaiabel). Hal ini berarti dengan model regresi berbeda tidak menjamin ketepatan dugaan akan meningkat dengan menggunakan tambahan peubah bebas, meskipun Se yang diperoleh memang lebih kecil dari Se dengan satu peubah bebas. Oleh karena itu, berdasarkan kesederhanaan model, tingkat akurasi dan ketepatan model maka penggunaan model dugaan volume pohon pada tinggi pohon diameter batang $10 \mathrm{~cm}$ sebaiknya menggunakan model nomor 1 dan 3 .
2. Model penduga volume pohon bebas cabang

Model-model penduga volume jati sampai tinggi pohon bebas cabang berdasarkan tingkat akurasinya disajikan pada Tabel 5 . Model dengan satu variabel parameter (diameter), yaitu model nomor 3 (model linear) merupakan model persamaan yang paling akurat digunakan untuk menaksir volume pohon jati, karena mempunyai nilai Se yang paling rendah, yaitu 3,03\%. Penambahan peubah tinggi menjadi model linear berganda seperti model nomor 1 dapat meningkatkan akurasi dugaan sampai $28 \%$, karena mempunyai Se yang semakin rendah, yaitu 2,18\%. Model power seperti model nomor 5 mempunyai $\mathrm{Se}=8,06 \%$, dengan penambahan variabel $\mathrm{T}$ diperoleh persamaan seperti model nomor 2 yang Se-nya semakin rendah, yaitu 2,98. Penambahan variabel $\mathrm{T}$ tersebut meningkatkan akurasi dugaan sampai $63 \%$. 
Tabel (Table) 5. Model-model dugaan volume pada tinggi pohon bebas cabang (Volume equation models on tree height of branch free stem)

\begin{tabular}{|c|l|l|c|c|}
\hline No. & $\begin{array}{c}|c| \\
\text { Model Regresi } \\
\text { Regression Models) }\end{array}$ & \multicolumn{1}{|c|}{$\begin{array}{c}\text { Persamaan Regresi } \\
\text { (Regression Equations) }\end{array}$} & Se (\%) & $\mathrm{R}^{2}(\%)$ \\
\hline 1 & Linear & $\widetilde{\mathrm{v}}=-0,191+0,013 \mathrm{D}+0,014 \mathrm{~T}$ & 2,18 & 93,40 \\
2 & Power & $\widetilde{\mathrm{v}}=0,00011 \mathrm{D}^{2,017} \mathrm{~T}^{0,631}$ & 2,98 & 99,00 \\
3 & Linear & $\widetilde{\mathrm{v}}=-0,120+0,013 \mathrm{D}$ & 3,03 & 87,11 \\
4 & Kuadrati & $\widetilde{\mathrm{v}}=-0,123+0,014 \mathrm{D}-0,000007 \mathrm{D}^{2}$ & 3,05 & 87,11 \\
5 & Power & $\widetilde{\mathrm{v}}=0,000245 \mathrm{D}^{2,109}$ & 8,06 & 92,50 \\
\hline
\end{tabular}

Keterangan (Remark):

$\widetilde{\mathrm{V}}=$ Dugaan volume pada tinggi pohon bebas cabang (Volume estimation on tree height of branch free stem)

$\mathrm{D}=$ Diameter setinggi dada (Diameter at breast height)

$T=$ Tinggi pohon bebas cabang (Tree height of branch free stem)

Tabel(Table) 6. SA dan SR persamaan regresi volume pohon (Agregative deviation and mean deviation of volume regression equations on tree height of branch free stem)

\begin{tabular}{|l|l|c|c|c|}
\hline No. & \multicolumn{1}{|c|}{$\begin{array}{c}\text { Persamaan Regresi } \\
\text { (Regression Equations) }\end{array}$} & SA (\%) & SR (\%) & Keterangan (Remarks) \\
\hline 1 & $\widetilde{\mathrm{v}}=-0,120+0,013 \mathrm{D}$ & 6,68 & 16,23 & Satu variabel \\
2 & $\widetilde{\mathrm{v}}=-0,123+0,014 \mathrm{D}-0,000007 \mathrm{D}^{2}$ & 2,64 & 16,25 & \\
3 & $\widetilde{\mathrm{v}}=0,000245 \mathrm{D}^{2,109}$ & 0,55 & 14,61 & \\
\hline 4 & $\widetilde{\mathrm{v}}=-0,191+0,013 \mathrm{D}+0,014 \mathrm{~T}$ & 3,11 & 16,75 & Dua variabel \\
5 & $\widetilde{\mathrm{v}}=0,00011 \mathrm{D}^{2,017} \mathrm{~T}^{0,631}$ & 2,80 & 5,42 & \\
\hline
\end{tabular}

Uji kesaksamaan model penduga volume pohon bebas cabang disajikan pada Tabel 6 . Berdasarkan nilai simpangan agregatifnya, semua model cenderung menduga volume pohon overestimate dengan nilai volume aktual. Model nomor 3 (power dengan satu variabel) mempunyai penyimpangan dugaan overestimate yang relatif paling rendah karena mempunyai nilai SA dan SR yang paling kecil.

\section{Model penduga volume pohon sampai tinggi pangkal tajuk \\ Model-model penduga volume jati sampai}

tinggi pangkal tajuk berdasarkan tingkat akurasinya (Se yang rendah) disajikan pada Tabel 7 . Untuk satu variabel, model kuadrati (model nomor 3) mempunyai kesalahan baku yang paling rendah, berarti menduga volume pohon jati sampai tinggi pangkal tajuk yang paling akurat. Berdasarkan nilai Se, penambahan variabel $\mathrm{T}$ menjadi model nomor 1 dari model linear satu variabel (model nomor 4) dapat meningkatkan akurasi dugaan sampai $28 \%$. Model power dari model nomor 5 menjadi model nomor 2 , akurasi dugaan meningkat sampai $62 \%$.

Tabel(Table) 7. Model-model dugaan volume pada tinggi pohon pangkal tajuk (Volume estimation models on tree height of crown base)

\begin{tabular}{|c|c|l|c|c|}
\hline No. & $\begin{array}{c}\text { Model Regresi } \\
\text { (Regression Models) }\end{array}$ & \multicolumn{1}{|c|}{$\begin{array}{c}\text { Persamaan Regresi } \\
\text { (Regression Equations) }\end{array}$} & Se (\%) & $\mathrm{R}^{2}(\%)$ \\
\hline 1 & Linear & $\widetilde{\mathrm{v}}=-0,192+0,013 \mathrm{D}+0,016 \mathrm{~T}$ & 2,06 & 93,60 \\
2 & Power & $\widetilde{\mathrm{v}}=0,00011 \mathrm{D}^{2,014} \mathrm{~T}^{0,663}$ & 2,81 & 99,10 \\
3 & Kuadrati & $\widetilde{\mathrm{v}}=-0,070+0,008 \mathrm{D}-0,00013 \mathrm{D}^{2}$ & 2,85 & 87,77 \\
4 & Linear & $\widetilde{\mathrm{v}}=-0,119+0,013 \mathrm{D}$ & 2,87 & 87,48 \\
5 & Power & $\widetilde{\mathrm{v}}=0,00025 \mathrm{D}^{2,084}$ & 7,42 & 93,40 \\
\hline
\end{tabular}


Tabel (Table) 8. SA dan SR persamaan regresi volume pohon (Agregative deviation and mean deviation of volume regression estimation on tree height of crown base)

\begin{tabular}{|l|l|c|c|c|}
\hline No. & \multicolumn{1}{|c|}{$\begin{array}{c}\text { Persamaan Regresi } \\
\text { (Regression Equations) }\end{array}$} & SA (\%) & SR (\%) & $\begin{array}{c}\text { Keterangan } \\
\text { (Remarks) }\end{array}$ \\
\hline 1 & $\widetilde{\mathrm{V}}=-0,119+0,013 \mathrm{D}$ & 0,84 & 16,28 & Satu variabel \\
2 & $\widetilde{\mathrm{v}}=-0,070+0,008 \mathrm{D}-0,00013 \mathrm{D}^{2}$ & 76,04 & 75,98 & \\
3 & $\widetilde{\mathrm{v}}=0,00025 \mathrm{D}^{2,084}$ & $-0,33$ & 13,74 & Dua variabel \\
\hline 4 & $\widetilde{\mathrm{v}}=-0,192+0,013 \mathrm{D}+0,016 \mathrm{~T}$ & $-3,85$ & 17,93 & \\
5 & $\widetilde{\mathrm{v}}=0,00011 \mathrm{D}^{2,014} \mathrm{~T}^{0,663}$ & $-1,02$ & 5,02 & \\
\hline
\end{tabular}

\section{Korelasi Antar Peubah Penduga volume Pohon}

Korelasi antara diameter dan beberapa tinggi pohon jati, yang paling erat adalah dengan tinggi pohon sampai pada diameter batang $10 \mathrm{~cm}$, yaitu $\mathrm{r}=0,812$ (Tabel 9). Pengaruh tinggi pohon sampai tinggi tersebut terhadap besaran diameter dbh hanya sampai $65 \%$, kurang lebih $35 \%$ besaran diameter dbh dipengaruhi oleh faktor lain. Oleh karena itu, dalam menduga volume dengan menggunakan dua variabel, tambahan parameter tinggi relatif sedikit dapat meningkatkan akurasi dugaan yaitu perbedaan Se yang rendah (Tabel 4). Sedangkan pengaruh tinggi pohon yang lain (bebas cabang dan pangkal tajuk) terhadap besar- an diameter kurang dari $1 \%$. Hampir $99 \%$ besaran diameter dipengaruhi oleh faktor lain sehingga menduga volume pohon dengan menggunakan dua variabel, tambahan parameter tinggi pohon dapat meningkatkan akurasi dugaan, yaitu perbedaan Se yang relatif tinggi (Tabel 6 dan 8).

Pada Tabel 7 dan 9 dapat dilihat bahwa, justru penduga dengan satu variabel (diameter) mempunyai SA yang paling rendah. Hubungan volume pohon pada semua tinggi pohon (tinggi pohon pada diameter batang $10 \mathrm{~cm}$, bebas cabang dan tinggi pangkal tajuk) dengan diameter (dbh) relatif kuat, rata-rata hampir $90 \%$ besaran volume pohon karena pengaruh diameter.

Tabel(Table) 9. Korelasi antara diameter dengan tinggi dan volume pohon (Correlation between diameter with height and volume of tree )

\begin{tabular}{|c|c|c|c|}
\hline No & Variabel (Variables) & $\begin{array}{c}\text { Koefesien Korelasi } \\
\text { (Correlation Coefficient) } \\
(\mathrm{r})\end{array}$ & $\begin{array}{c}\text { Koefesien Determinasi } \\
\text { (Determination Coefficient }) \\
\left(\mathrm{r}^{2}\right)\end{array}$ \\
\hline 1 & $\begin{array}{l}\text { Diameter dan tinggi pohon pada } \\
\text { diameter batang } 10 \mathrm{~cm}\end{array}$ & 0,812 & 0,659 \\
\hline 2 & $\begin{array}{l}\text { Diameter dan tinggi pohon bebas } \\
\text { cabang }\end{array}$ & 0,097 & 0,009 \\
\hline 3 & $\begin{array}{l}\text { Diameter dan tinggi pohon sampai } \\
\text { pangkal tajuk }\end{array}$ & 0,092 & 0,008 \\
\hline 4 & Diameter dan tinggi pohon total & 0,714 & 0,510 \\
\hline 5 & $\begin{array}{l}\text { Diameter dan volume pohon sampai } \\
\text { tinggi diameter } 10 \mathrm{~cm}\end{array}$ & 0,962 & 0,925 \\
\hline 6 & $\begin{array}{l}\text { Diameter dan volume pohon sampai } \\
\text { tinggi bebas cabang }\end{array}$ & 0,933 & 0,870 \\
\hline 7 & $\begin{array}{l}\text { Diameter dan volume pohon sampai } \\
\text { tinggi pangkal tajuk }\end{array}$ & 0,935 & 0,874 \\
\hline
\end{tabular}




\section{Riap Tegakan Jati}

Perkembangan riap tegakan hutan rakyat jati di Nusa Penida disajikan pada Tabel 10. Riap tegakan jati di Desa Bunga Mekar relatif paling cepat dibandingkan dengan lokasi-lokasi yang lain, yaitu pada umur tegakan 9 tahun riap tahunan (MAI) diameter $=2,25 \mathrm{~cm} /$ tahun dan MAI-tinggi pohon 1,97 m/tahun. Sedangkan riap tegakan yang paling rendah adalah tanaman jati di Desa Kutampi, yaitu riap diameter dan tingginya tidak lebih dari $1 \mathrm{~cm} /$ tahun dan 1 $\mathrm{m} /$ tahun. Perbedaan tumbuh riap ini sangat berkaitan dengan kondisi tapak (tempat tumbuh) dan tehnik pemeliharaan yang dilakukan oleh masyarakat petani. Pernyataan ini sebagian didukung oleh Alrasjid (1991) yang mengemukakan bahwa faktor kualitas lahan sangat berperan dalam mempengaruhi pertumbuhan tanaman yaitu kandungan humus, kandungan unsur nitrogen, altitude, drainase tanah, solum tanah, curah hujan, jumlah musim (hujan-kemarau) per tahun dan faktor tekstur tanah.

Hasil penelitian ini tidak berbeda jauh dengan hasil penelitian yang telah dilakukan di Timor (Nusa Tenggara Timur) pada tegakan hutan tanaman di dalam kawasan hutan. Tegakan jati di Takari (Kabupaten kupang) pada umur 10 tahun adalah MAI- diameter $1,4 \mathrm{~cm} /$ tahun dan MAI-tinggi tegakan 1,5 m/tahun, tegakan jati di Polen (Kabupaten Timor Tengah Selatan) pada umur 8 tahun adalah MAI-diameter $1,0 \mathrm{~cm} /$ tahun dan MAI-tinggi tegakan $0,8 \mathrm{~m} /$ tahun (Susila, 2009). Kondisi tempat tumbuh tanaman jati di Timor relatif hampir sama dengan tempat tumbuh jati di Nusa Penida, yaitu tanah berbatu, tanah kapur, solum tanah yang dangkal, suhu tinggi, musim hujan hanya sampai 3 - 4 bulan. Dalam kondisi tapak yang optimal, riap volume tanaman jati dapat mencapai 7,9 - 10 $\mathrm{m}^{3} /$ ha/tahun (http://sahabatlingkungan.multiply. $\mathrm{com} /$ journal/item/19, 2008,). Informasi dari KPH Nganjuk menyebutkan bahwa riap diameter trubusan akar jati mencapai $25-28 \mathrm{~cm}$ pada umur 20 tahun, sedangkan riap diameter tanaman aslinya hanya $1-2 \mathrm{~cm} /$ tahun (http://www. suarakarya-online.com/news.htmlid=123303, 2005).

Sebenarnya riap tegakan jati di Nusa Penida bisa ditingkatkan melalui pemeliharaan yang intensif, yaitu dua kali setahun dilakukan pendangiran dan pembersihan terhadap tegakan jati menjelang penanaman palawija. Kondisi ini telah dilakukan terhadap tegakan jati di Desa Batukandik (Nusa Penida), yaitu pada umur tanaman jati 3 tahun MAI-diameter $=2,10$ $\mathrm{cm} /$ tahun dan MAI-tinggi $=1,25 \mathrm{~m} /$ tahun (Anonim, 2010). Sedangkan tanaman yang hanya dilakukan pembersihan saja (tanpa pendangiran/ penggemburan tanah), riap tegakannya adalah 1) tegakan jati umur 4 tahun di Dusun Soyor, Tanglad, MAI-diameter $0,70 \mathrm{~cm} /$ tahun dan MAItinggi $0,24 \mathrm{~m} /$ tahun ; 2 ) tegakan jati umur 5 tahun di Banjar Penyancangan, Tanglad, MAI-diameter $=0,80 \mathrm{~cm} /$ tahun dan MAI-tinggi $=0,32 \mathrm{~m} /$ tahun; dan 3) tegakan jati umur 4 tahun Di Banjar Kepuh, Tanglad, MAI-diameter $=0,60 \mathrm{~cm} /$ tahun dan MAI-tinggi $=0,22 \mathrm{~m} /$ tahun (Anonim, 2010).

Tabel (Table) 10. Perkembangan riap tegakan hutan rakyat jati di setiap lokasi (Increment trend of people forest stand of teakwood at every location)

\begin{tabular}{|c|c|c|c|c|c|}
\hline No & Lokasi (Location) & $\mathrm{D}(\mathrm{cm})$ & $\mathrm{T}(\mathrm{m})$ & MAI-D $(\mathrm{cm} / \mathrm{th})$ & MAI-T (m/th) \\
\hline 1 & $\begin{array}{l}\text { Tegakan th 1991, jarak tanam 3-5 m di } \\
\text { Desa Suana }\end{array}$ & 19,2 & 16,8 & 1,07 & 0,94 \\
\hline 2 & $\begin{array}{l}\text { Tegak an th } 1996-1997 \text {, jarak tanam } \\
3-5 \text { m di Desa Pejukutan }\end{array}$ & 21,3 & 17,9 & $1,64-1,77$ & $1,38-1,49$ \\
\hline 3 & $\begin{array}{l}\text { Tegakan th } 2000 \text {, jarak tanam 3-6 m di } \\
\text { Desa Bunga Mekar }\end{array}$ & 20,2 & 17,7 & 2,25 & 1,97 \\
\hline 4 & $\begin{array}{l}\text { Tegakan th } 1998-2002 \text {, jarak tanam } \\
2-5 \mathrm{~m} \text {, jarak tanam 3-5 m di Desa Ped }\end{array}$ & 13,9 & 18,36 & $1,27-2,00$ & $1,67-2,62$ \\
\hline 5 & $\begin{array}{l}\text { Tegakan th } 1997-2003 \text {, jarak tanam } \\
\text { 3-7 m di Desa Klumpu }\end{array}$ & 13,9 & 14,9 & $1,16-2,32$ & $1,24-2,48$ \\
\hline 6 & $\begin{array}{l}\text { Tegakan th } 1983-1985 \text {, jarak tanam } \\
2-5 \mathrm{~m} \text { di Desa Kutampi }\end{array}$ & 23,2 & 17,54 & $0,89-0,97$ & $0,67-0,73$ \\
\hline
\end{tabular}

Keterangan (Remarks):

$=\mathrm{D}, \mathrm{T} \quad:$ Diameter $(\mathrm{dbh})$ dan tinggi pohon total (Diameter and height of total tree)

= MAI-D,T : Riap diameter dan tinggi pohon pada umur tertentu (Mean annual increment of diameter and tree height on every age of stand) 


\section{KESIMPULAN}

\section{A. Kesimpulan}

1) Berdasarkan kesederhanaan model dan akurasi dugaan, model-model penduga volume pohon jati ( $\widetilde{v})$ dengan variabel diameter dbh (D) dan tinggi pohon tertentu (T) adalah :

= Model penduga volume sampai tinggi pohon pada diameter batang $10 \mathrm{~cm}$ untuk satu variabel adalah $\widetilde{\mathrm{v}}=0,00006 \mathrm{D}^{2,660}$ dan $\tilde{\mathrm{v}}=-0,248+0,023 \mathrm{D}$, dan untuk dua variabel adalah $\tilde{\mathrm{v}}=0,00012 \mathrm{D}^{1,967} \mathrm{~T}^{0,673}$, dimana $\mathrm{T}=$ tinggi pohon pada diameter batang/cabang $10 \mathrm{~cm}$.

$=$ Model penduga volume sampai tinggi pohon bebas cabang adalah $\widetilde{\mathrm{v}}=0,000245$ $\mathrm{D}^{2,109}, \tilde{\mathrm{V}}=-0,120+0,013 \mathrm{D}$, dan $\tilde{\mathrm{V}}=$ $0,00011 \mathrm{D}^{2,017} \mathrm{~T}^{0,631}$, dimana $\mathrm{T}=$ tinggi pohon sampai bebas cabang.

$=$ Model penduga volume sampai tinggi pohon pangkal tajuk adalah $\widetilde{\mathrm{v}}=0,00025$ $\mathrm{D}^{2,084}, \widetilde{\mathrm{V}}=-0,119+0,013 \mathrm{D}$ dan $\tilde{\mathrm{V}}=$ $0,00011 \mathrm{D}^{2,014} \mathrm{~T}^{0,663}$, dimana $\mathrm{T}=$ tinggi pohon sampai pangkal tajuk.

2) Angka bentuk batang jati rata-rata (f) adalah adalah 0,72. Penggunaan angka bentuk batang $(F)=0,70$ menghasilkan dugaan yang relatif kurang dari nilai sebenarnya sebesar $2,8 \%$.

3) Riap jati tertinggi terjadi pada lokasi tegakan hutan rakyat di desa Bunga Mekar, yaitu pada umur tegakan 9 tahun, riap diameter adalah $2,25 \mathrm{~cm} /$ tahun dan riap tinggi pohon adalah $1,97 \mathrm{~m} /$ tahun. Sedangkan riap tegakan yang paling rendah di Desa Kutampi, yaitu pada umur tegakan 24 - 26 tahun, riap diameter adalah $0,83 \mathrm{~cm} /$ tahun dan riap tinggi adalah $0,70 \mathrm{~m} /$ tahun.

\section{B. SARAN}

Untuk mengetahui prediksi volume pohon jati di hutan rakyat Nusa Penida pada selang diameter pohon (dbh) antara $10 \mathrm{~cm}$ sampai dengan $30 \mathrm{~cm}$ dapat menggunakan model sebagai berikut : 1) Penduga volume sampai tingi pohon pada diameter batang/cabang $10 \mathrm{~cm}$ adalah $\widetilde{\mathrm{v}}=$ $\left.0,00006 \mathrm{D}^{2,660}, 2\right)$ sampai tinggi pohon bebas cabang adalah $\tilde{v}=0,000245 \mathrm{D}^{2,109}$, dan 3) sampai tinggi pohon pangkal tajuk adalah $\widetilde{\mathrm{V}}=0,00025$ $\mathrm{D}^{2,084}$.

\section{DAFTAR PUSTAKA}

Alrasjid, H.1991. Faktor Kualitas Lahan Pembatas untuk Pertumbuhan Gmelina arborea. Buletin Penelitian Hutan, 540 : 1-23, Pusat Litbang Hutan. Bogor.

Anonim. 1994. Tinjauan Sifat dan Penggunaan Kayu Jati Jawa Barat. Majalah Bulanan PT Perhutani. Duta Rimba. No. 163-164/XX : 40 - 43.

Anonim. 2010. Laporan Kegiatan Pengamatan Riap Pertumbuhan Demplot Hutan Rakyat di Nusa Penida Kabupaten Klungkung Provinsi Bali Tahun 2009. Kerjasama Pusat Penelitian dan Pengembangan Hutan Tanaman dan Balai Penelitian Kehutanan Mataram. Mataram. Tidak diterbitkan

Badan Litbang Kehutanan. 2004. Laporan Kunjungan Lapangan dalam rangka Rehabilitasi Hutan dan Lahan untuk Peningkatan Kesejahteraan Masyarakat di Nusa Penida. Tidak diterbitkan.

Bustomi, S., Soemarna, K. 1986. Tabel Isi Pohon Sementara Jenis Meranti (Shorea sp.) untuk Kabupaten Bangkinang Riau. Buletin Penelitian Hutan. Pusat Penelitian dan Pengembangan Hutan Bogor.

Dinas Kehutanan Provinsi Bali. 2006. Statistik Dinas Kehutanan Provinsi Bali Tahun 2005. Dinas Kehutanan Provinsi Bali, Denpasar.

DKLH. 2002. Proposal Kegiatan Rehabilitasi Hutan dan Lahan dengan Pembuatan Hutan Rakyat dan Kebun Rakyat di Kecamatan Nusa Penida Tahun Anggaran 2003. Dinas Kebersihan dan Lingkungan Hidup Kabupaten Klungkung. Semara Pura. Tidak diterbitkan.

Harbagung. 2002. Kuantifikasi Pertumbuhan dan Hasil pada Hutan Tanaman Jenis-Jenis Prioritas (Andalan Setempat). Badan Penelitian dan Pengembangan Kehutanan. Jakarta.

http://www.suarakarya-online.com/news. htmlid= 123303. 2008. Pengelolaan Hutan KPH Nganjuk Mampu Lipatgandakan Produksi. di Akses tanggal 20 september 2010.

http://sahabatlingkungan.multiply.com/journal/item/ 19. 2005. Hutan Rakyat, Sarana Pelestarian Alam dan Penambah Pendapatan. Akses tanggal 20 Septembet 2010.

Husch, B. 1963. Forest Mensuration and Statistics. The Ronald Press Company. New York

Irianto, A. 2006. Statistik, Konsep Dasar dan Aplikasinya. Prenada Media Group. Jakarta

Jonathan, S. 2006. Panduan Cepat dan Mudah SPSS 11.5. Edisi I, hal 65 - 95. CV. Andi offset. Yogyakarta 
Prodan, M. 1965. Forest Biometric. Perganon, Oxford-London.

Simon, H. 2007. Metode Inventore Hutan. Pustaka Pelajar. Yogyakarta
Susila, I.W.W. 2009. Riap Hutan Tanaman Jati dan Cendana di Nusa Tenggara Timur. Jurnal Penelitian Hutan Tanaman, Vol. 6 No. 3 : 157 185. Pusat Penelitian dan Pengembangan Hutan Tanaman. Bogor. 
Lampiran (Appendix) 1.

\section{MODEL REGRESI PENDUGA VOLUME POHON JATI TINGGI DIAMETER BATANG $10 \mathrm{CM}$}

Dependent variable.. VD10

Method.. LINEAR

$\begin{array}{ll}\text { Multiple R } & 0,96234 \\ \text { R Square } & 0,92611 \\ \text { Standard Error } & 0,03759\end{array}$

Analysis of Variance:

DF Sum of Squares Mean Square

$\begin{array}{lccc}\text { Regression } & 1 & 2,0361894 & 2,0361894 \\ \text { Residuals } & 115 & 0,1624681 & 0,0014128\end{array}$

$F=1441,27838 \quad$ Signif $F=0,0000$

Variables in the Equation

$\begin{array}{lrcccr}\text { Variable } & \text { B } & \text { SE B } & \text { Beta } & \text { T } & \text { Sig T } \\ \text { DBH } & 0,022741 & 0,000599 & 0,962344 & 37,964 & 0,0000 \\ \text { (Constant) } & -0,247404 & 0,012455 & -19,864 & 0,0000 & \end{array}$

Variables Entered/Removed(b)

\begin{tabular}{|l|c|c|c|}
\hline Model & $\begin{array}{c}\text { Variables } \\
\text { Entered }\end{array}$ & $\begin{array}{c}\text { Variables } \\
\text { Removed }\end{array}$ & Method \\
\hline 1 & DBH1(a) &. & Enter \\
\hline
\end{tabular}

a All requested variables entered.

b Dependent Variable: VD101 adalah log dari VD10

\begin{tabular}{|l|c|c|c|c|}
\hline Model & R & R Square & $\begin{array}{c}\text { Adjusted } \\
\text { R Square }\end{array}$ & $\begin{array}{c}\text { Std. Error of } \\
\text { the Estimate }\end{array}$ \\
\hline 1 & $0,980(a)$ & 0,961 & 0,960 & 0,07199 \\
\hline
\end{tabular}

a Predictors: (Constant), DBH1 adalah log dari DBH

ANOVA(b)
\begin{tabular}{|l|l|r|r|r|r|c|}
\hline Model & & $\begin{array}{r}\text { Sum of } \\
\text { Squares }\end{array}$ & df & Mean Square & F & Sig. \\
\hline 1 & Regression & 14,597 & 1 & 14,597 & 2816,820 & $0,000(\mathrm{a})$ \\
\hline & Residual & 0,596 & 115 & 0,005 & & \\
\hline & Total & 15,193 & 116 & & & \\
\hline
\end{tabular}

a Predictors: (Constant), DBH1

b Dependent Variable: VD101 
Coefficients(a)

\begin{tabular}{|l|l|r|r|r|r|r|}
\hline Model & & \multicolumn{2}{|c|}{$\begin{array}{c}\text { Unstandardized } \\
\text { Coefficients }\end{array}$} & $\begin{array}{c}\text { Standardized } \\
\text { Coefficients }\end{array}$ & \multicolumn{1}{c|}{$\mathrm{t}$} & \multicolumn{1}{c|}{ Sig. } \\
\hline & & \multicolumn{1}{c|}{ B } & Std. Error & Beta & & \\
\hline 1 & (Constant) & $-4,214$ & 0,065 & & $-65,299$ & 0,000 \\
\hline & DBH1 & 2,660 & 0,050 & 0,980 & 53,074 & 0,000 \\
\hline
\end{tabular}

a Dependent Variable: VD101

\begin{tabular}{|l|c|c|c|}
\hline Model & $\begin{array}{c}\text { Variables } \\
\text { Entered }\end{array}$ & $\begin{array}{c}\text { Variables } \\
\text { Removed }\end{array}$ & Method \\
\hline 1 & $\begin{array}{r}\text { TD101, } \\
\text { DBH1(a) }\end{array}$ & & Enter \\
\hline
\end{tabular}

a All requested variables entered.

b Dependent Variable: VD101

Model Summary

\begin{tabular}{|l|c|r|r|r|}
\hline Model & R & R Square & $\begin{array}{c}\text { Adjusted } \\
\text { R Square }\end{array}$ & $\begin{array}{r}\text { Std. Error of } \\
\text { the Estimate }\end{array}$ \\
\hline 1 & $0,993(\mathrm{a})$ & 0,986 & 0,986 & 0,04311 \\
\hline
\end{tabular}

a Predictors: (Constant), TD101, DBH1

ANOVA(b)

\begin{tabular}{|l|l|r|r|r|c|c|}
\hline Model & & $\begin{array}{r}\text { Sum of } \\
\text { Squares }\end{array}$ & df & Mean Square & F & Sig. \\
\hline 1 & Regression & 14,981 & 2 & 7,490 & 4030,004 & $0,000(\mathrm{a})$ \\
\hline & Residual & 0,212 & 114 & 0,002 & & \\
\hline & Total & 15,193 & 116 & & & \\
\hline
\end{tabular}

a Predictors: (Constant), TD101, DBH1

b Dependent Variable: VD101

Coefficients(a)

\begin{tabular}{|l|l|c|c|c|c|c|}
\hline \multirow{2}{*}{ Model } & & \multicolumn{2}{|c|}{$\begin{array}{c}\text { Unstandardized } \\
\text { Coefficients }\end{array}$} & $\begin{array}{c}\text { Standardized } \\
\text { Coefficients }\end{array}$ & $\mathrm{t}$ & Sig. \\
\hline & & $\mathrm{B}$ & Std. Error & Beta & & \\
\hline 1 & (Constant) & $-3,923$ & 0,044 & & $-89,901$ & 0,000 \\
\hline & DBH1 & 1,967 & 0,057 & 0,725 & 34,653 & 0,000 \\
\hline & TD101 & 0,673 & 0,047 & 0,301 & 14,374 & 0,000 \\
\hline
\end{tabular}

a Dependent Variable: VD101 